\title{
Triterpenoids from the Herbs of Salicornia bigelovii
}

\author{
Yu Shan ${ }^{1,2}$, Huan Li ${ }^{1}$, Fuqin Guan ${ }^{1}$, Yu Chen ${ }^{1}$, Min Yin ${ }^{1}$, Ming Wang ${ }^{1}$, Xu Feng ${ }^{1}$ and \\ Qizhi Wang ${ }^{1, *}$
}

Received: 16 September 2015 ; Accepted: 5 November 2015 ; Published: 12 November 2015

Academic Editor: Derek J. McPhee

1 Jiangsu Key Laboratory for Bioresources of Saline Soils, Institute of Botany, Jiangsu Province and Chinese Academy of Sciences, Nanjing 210014, China; attilayu@hotmail.com (Y.S.); lihuan405@sina.cn (H.L.); tube1031aaa@126.com (F.G.); chenyu.1007@163.com (Y.C.); epmin@sohu.com (M.Y.); wangmingwm0208@sina.com (M.W.); fengxucnbg@cnbg.net (X.F.)

2 Jiangsu Provincial Platform for Conservation and Utilization of Agricultural Germplasm, Nanjing 210014, China

* Correspondence: wangqizhi@cnbg.net; Tel.: +86-25-8434-7159

\begin{abstract}
A new nortriterpene saponin, 3-O- $\beta$-D-glucuronopyranosyl-30-norolean-12,20(29)-dien-23oxo-28-oic acid, namely bigelovii D (11), was isolated from the hydroalcoholic extract of herbs of Salicornia bigelovii along with 10 known saponins (1-10). Their chemical structures were identified on the basis of spectroscopic analyses including two-dimensional NMR and a comparison with literature data. Some of these compounds showed potent antifungal activities in vitro. Compounds 3, 4, 5, 6, 7, 10 and 11 demonstrated potent inhibitory activities against Colletotrichum gloeosporioides and compound 11 displayed broad-spectrum inhibitory activity against Alternaria alternata, A. solani, Botrytis cinerea, C. gloeosporioides, Fusarium graminearum, F. verticilloides, Thanatephorus cucumeris and Sclerotinia sclerotiorum, with $\mathrm{EC}_{50}$ values ranging from 13.6 to $36.3 \mu \mathrm{g} / \mathrm{mL}$.
\end{abstract}

Keywords: Salicornia bigelovii Torr.; nortriterpenoid saponins; antifungal activity

\section{Introduction}

Salicornia bigelovii is a salt-tolerant land plant that grows on salt marshes and muddy seashores and is widespread in tropical and subtropical North America, Asia and Europe. It belongs to Salicornia (Chenopodiaceae), which is a genus of annual, apparently leafless, halophytic herbs that have articulated and succulent stems [1]. It was reviewed as an oil seed crop and seasoned vegetable with direct seawater irrigation [2]. Recently, the consumption of this plant as functional foods and medicinal plants has increased considerably because of their beneficial effects in the treatment of constipation, obesity, diabetes and cancer [3]. During our ongoing screening for biologically active constituents [1], there were no previous reports of the inhibitory activity against plant pathogens of extracts from S. bigelovii. It has been reported that S. bigelovii contains a diverse range of bioactive phytochemicals, including chlorogenic acid derivatives, quercetin glucosides and triterpenoid saponins [1,4-6]. In order to examine its chemical constituents further, the present study describes the isolation of 11 nortriterpene and triterpene analogues, including a new nortriterpene saponin, 3-O- $\beta$-D-glucuronopyranosyl-30-norolean-12,20(29)dien-23-oxo-28-oic acid, namely bigelovii $\mathrm{D}$, as well as their inhibitory activities against plant pathogens.

\section{Results and Discussion}

The powder of the herbs was extracted using $80 \%$ ethanol, and the concentrated extracts were partitioned successively with petroleum ether (PE), ethyl acetate (EtOAc) and $n$-BuOH. Column 
chromatography of the $n$-BuOH-soluble fraction yielded one new compound (11) and 10 known compounds (1-10) (Figure 1).
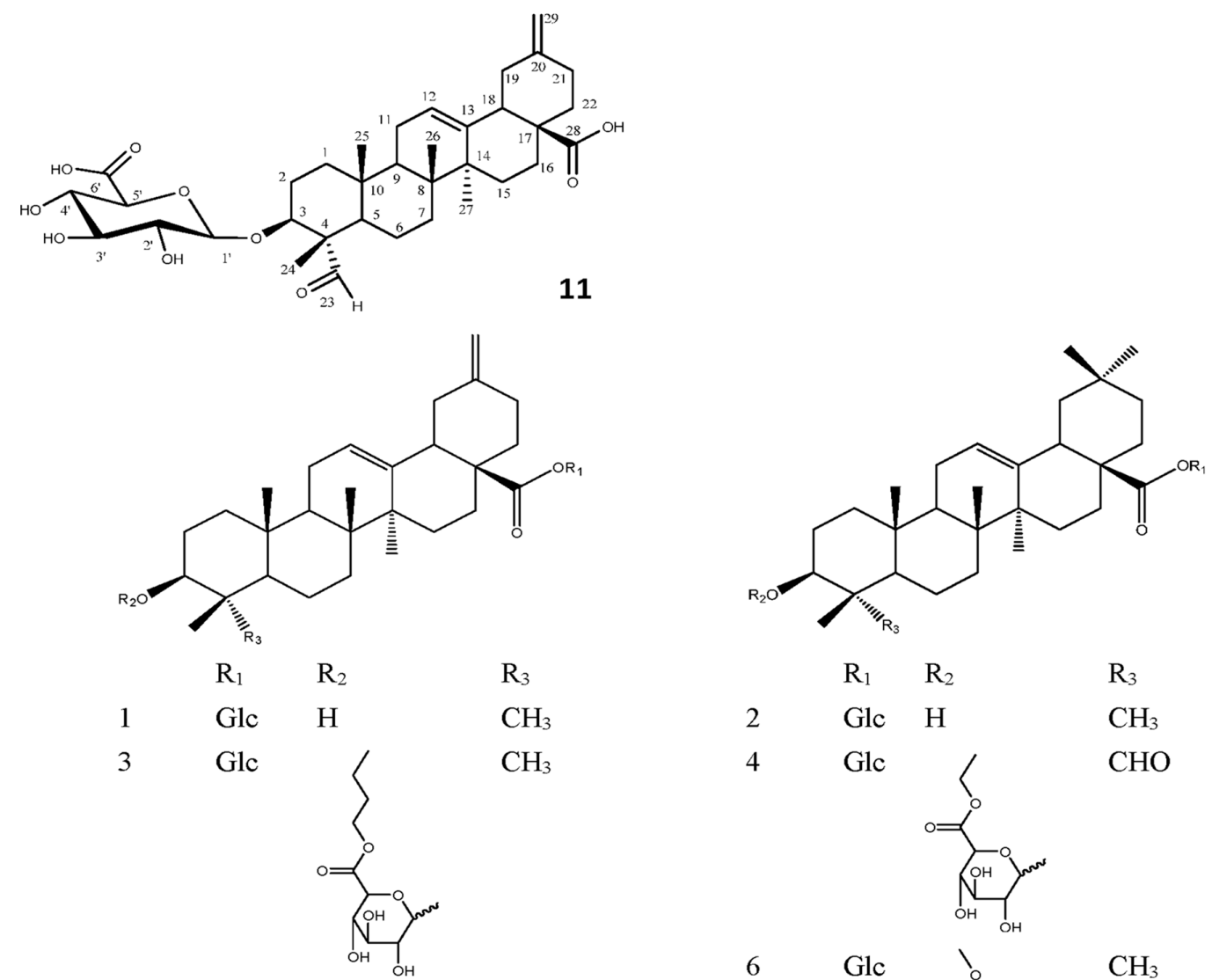

$\mathrm{R}_{3}$

$\mathrm{R}_{1} \quad \mathrm{R}_{2}$

$\mathrm{R}_{3}$

$\mathrm{CH}_{3}$

2 Glc $\mathrm{H}$

$\mathrm{CH}_{3}$

$\mathrm{CH}_{3}$

4

Glc

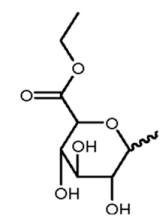

$\mathrm{CHO}$

5

Glc

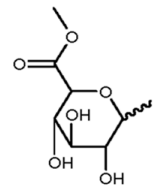

7

Glc

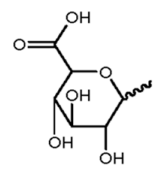

8

Glc

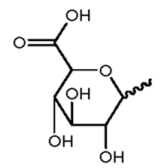

11

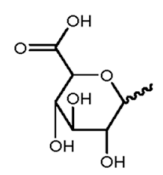

$\mathrm{CH}_{3}$

$\mathrm{CHO}$

$\mathrm{CH}_{3}$

6

Glc

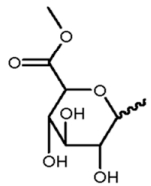

9

Glc

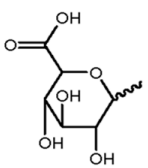

10

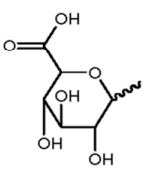

$\mathrm{CH}_{3}$

$\mathrm{CH}_{3}$

$\mathrm{CH}_{3}$

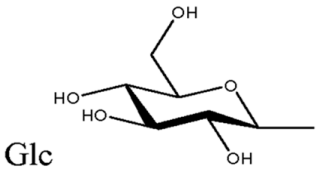

Figure 1. Structures of compounds 1-11.

Compound (11) was obtained as a white amorphous powder with a positive optical rotation $\left([\alpha]_{\mathrm{D}}^{20}+27.9(c\right.$ 0.479, MeOH)$)$. The IR spectrum of 11 showed absorption bands at 3412, 1705 and $1645 \mathrm{~cm}^{-1}$ ascribable to hydroxy, carboxy and olefin functions. The negative-ion high-resolution electrospray ionization mass spectrum (HR-ESI-MS) analysis revealed the molecular formula of $\mathbf{1 1}$ to be $\mathrm{C}_{35} \mathrm{H}_{50} \mathrm{O}_{10}$, showing a deprotonated molecule $[\mathrm{M}-\mathrm{H}]^{-}$at $m / z 629.3261$ (calc. for $\mathrm{C}_{35} \mathrm{H}_{49} \mathrm{O}_{10}$ : 
629.3326). The ${ }^{1} \mathrm{H}-\mathrm{NMR}$ and ${ }^{13} \mathrm{C}-\mathrm{NMR}$ (Table 1 ) spectra of $\mathbf{1 1}$, which were assigned by various NMR experiments showed signals assignable to four methyls $\left[\delta_{\mathrm{H}} 0.77,0.88,1.26,1.28\right.$ ( $3 \mathrm{H}$ each, all s, $\mathrm{H}_{3}-25$, $26,27,24)]$, one methine bearing an oxygen function $\left[\delta_{\mathrm{H}} 4.17(1 \mathrm{H}, \mathrm{dd}, J=4.5,11.6 \mathrm{~Hz}, \mathrm{H}-3)\right]$, three olefinic protons $\left[\delta_{\mathrm{H}} 4.77,4.73\right.$ (1H each, both s like, $\left.\mathrm{H}_{2}-29\right), 5.43(1 \mathrm{H}, \mathrm{br} \mathrm{d}$ like, $\left.\mathrm{H}-12)\right]$, an aldehyde group $\left[\delta_{\mathrm{H}} 9.73(1 \mathrm{H}, \mathrm{s})\right]$. These data were correlated with information from ${ }^{13} \mathrm{C}-\mathrm{NMR}$ spectrum. Two signals at $\delta_{\mathrm{H}} 122.7$ and 144.2 ascribable to $\mathrm{C}-12$ and $\mathrm{C}-13$ suggested a $\Delta^{12}$ oleanene skeleton. Four methyl resonances $\left(\delta_{C} 10.4,15.5,17.2,26.1\right)$, four sp2-hybridized carbon signals $\left(\delta_{C} 122.7,144.2\right.$, $149.0,107.0)$ and an aldehyde group $\left(\delta_{C} 206.8\right)$, and two carboxy carbon $\left(\delta_{C} 179.3\right.$ and $179.3, C-28$ and C- $6^{\prime}$ ) were shown in its ${ }^{13} \mathrm{C}$-NMR spectrum. The ${ }^{13} \mathrm{C}-\mathrm{NMR}$ spectrum of $\mathbf{1 1}$ displayed 35 carbon resonances of which 29 carbon signals were assigned to a noroleanic-acid-type triterpene moiety and six to a monosaccharide portion. The proton and carbon signals of $\mathbf{1 1}$ in the ${ }^{1} \mathrm{H}$ - and ${ }^{13} \mathrm{C}-\mathrm{NMR}$ spectra resembled those of glucopyranosiduronic acid $\left(6^{\prime}-\mathrm{COOH}\right)$. This assumption was supported by a set of 2D NMR experiments that provided decisive information concerning the structure of compound $\mathbf{1 1}$. The chemical shifts of all the individual protons and carbons of the sugar unit were assigned on the basis of ${ }^{1} \mathrm{H}-{ }^{1} \mathrm{H}$ COSY spectra analysis. The $\beta$-glucopyranosyluronic group, which was deduced from its ${ }^{3} J_{H-1, H-2}$ coupling constant of $7.8 \mathrm{~Hz}$, was placed at $\mathrm{C}-3$ of the aglycon on the basis of the HMBC correlation between the anomeric proton at $\delta_{\mathrm{H}} 4.84(1 \mathrm{H}, \mathrm{d}, J=7.8 \mathrm{~Hz})$ and the $\mathrm{C}-3$ carbon resonance at $\delta_{\mathrm{C}}$ 82.0. In the heteronuclear multiple bond correlations spectroscopy (HMBC) experiment (Figure 2), long-range correlations were observed between the following protons and carbons: $\mathrm{H}-5$ and $\mathrm{C}-4,10$; $\mathrm{H}-12$ and $\mathrm{C}-9,14 ; \mathrm{H}-18$ and $\mathrm{C}-12,13 ; \mathrm{H}-23$ and C-4, 24; H-24 and C-3, 4, 5, 23; H-25 and C-9; H-26 and C-7, 9; H-27 and C-9, 13, 15; H-29 and C-19, 21. The configuration of the glucuronic unit was established as $\mathrm{D}$ after hydrolysis of $1 \mathrm{~N} \mathrm{HCl}$, trimethylsilation, and determination of retention time by GC. On the basis of this evidence, the structure of $\mathbf{1 1}$ was characterized as shown. Thus the structure of $\mathbf{1 1}$ was deduced as 3-O- $\beta$-D-glucuronopyranosyl-30-norolean-12,20(29)-dien-23-oxo-28-oic acid and named bigelovii $\mathrm{D}$.

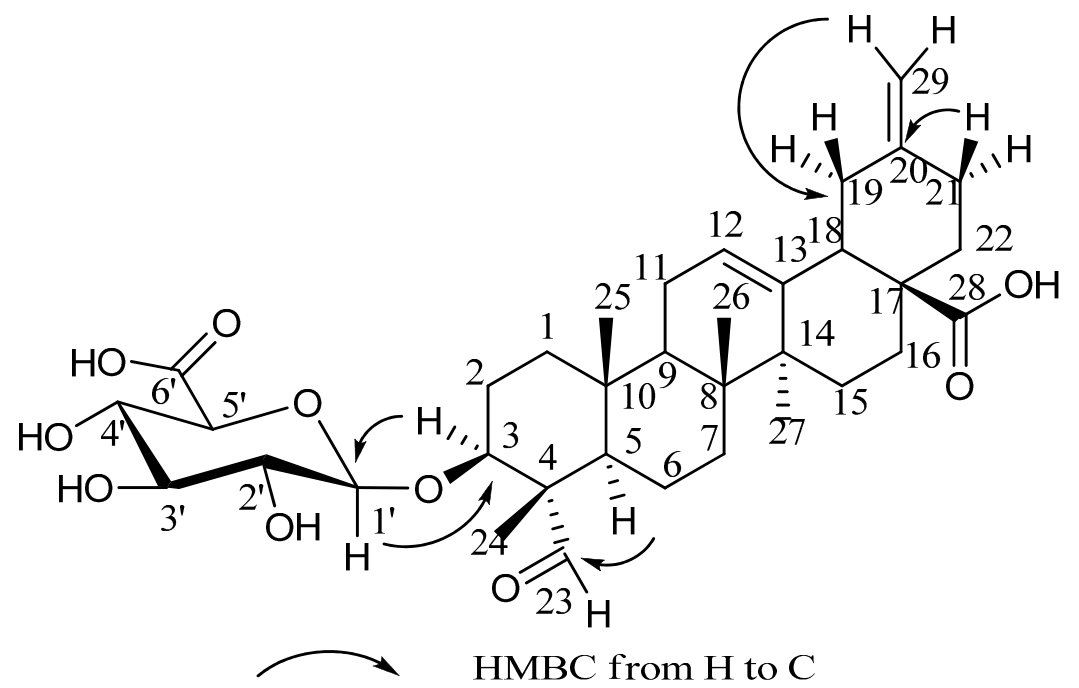

Figure 2. Key HMBC correlations for compounds 11.

The 10 known compounds were identified as pfaffine B (1), oleanolic acid 28-O- $\beta$-Dglucopyranoside (2), bigelovii A (3), 3-O-[(6'-ethyl-ester)-D-glucuronopyranosyl]-oleanolicacid-28$O-\beta$-D-glucopyranoside (4), 3-O-[(6'-methyl-ester)- $\beta$-D-glucuronopyranosyl]-30-norolean-12,20(29)dien-28-oic-28-O- $\beta$-D-glucuronopyranosyl ester (5), chikusetsusaponin IVa methyl ester (6), bigelovii B (7), boussingoside A2 (8), 3-O- $\beta$-D-glucuronopyranosyl-oleanolic acid 28-O- $\beta$-D-glucopyranoside (9) and 3-O- $\beta$-D-glucuronopyranosyl-oleanolic acid (10), respectively, by comparing their physical data (m.p., NMR, MS, and IR) with those reported in the literature [1,7-11]. 
Table 1. NMR spectroscopic data for compounds 11 in pyridine- $d_{5}\left({ }^{1} \mathrm{H}: 500 \mathrm{MHz},{ }^{13} \mathrm{C}: 125 \mathrm{MHz}\right)$.

\begin{tabular}{|c|c|c|c|c|c|}
\hline No. & ${ }^{1} \mathrm{H}-\mathrm{NMR}[\delta$ (ppm), mult., $J$ (Hz)] & ${ }^{13} \mathrm{C}-\mathrm{NMR}[\delta(\mathrm{ppm})]$ & DEPT & ${ }^{1} \mathrm{H}-{ }^{1} \mathrm{HCOSY}$ & НMBC \\
\hline $1 \alpha$ & $0.88(1 \mathrm{H}, \mathrm{m})$ & \multirow{2}{*}{$38.1(\mathrm{t})$} & \multirow{2}{*}{$\mathrm{CH}_{2}$} & \multirow{2}{*}{$\mathrm{H}-2$} & \multirow{6}{*}{$\mathrm{C}-1, \mathrm{C}-2$} \\
\hline $1 \beta$ & $1.39(1 \mathrm{H}, \mathrm{m})$ & & & & \\
\hline $2 \alpha$ & $1.85(1 \mathrm{H}, \mathrm{m})$ & \multirow{2}{*}{$25.1(t)$} & \multirow{2}{*}{$\mathrm{CH}_{2}$} & \multirow{2}{*}{ H-3, H-1 } & \\
\hline $2 \beta$ & $2.23(1 \mathrm{H}, \mathrm{m})$ & & & & \\
\hline 3 & $4.17(1 \mathrm{H}, \mathrm{dd}, J=4.5,11.6)$ & $82.0(\mathrm{~d})$ & $\mathrm{CH}$ & $\mathrm{H}-2$ & \\
\hline 4 & & $55.4(\mathrm{~s})$ & $\mathrm{C}$ & & \\
\hline 5 & $1.31(1 \mathrm{H}, \mathrm{m})$ & $47.7(\mathrm{~d})$ & $\mathrm{CH}$ & $\mathrm{H}-23$ & \multirow[t]{5}{*}{$\mathrm{C}-4, \mathrm{C}-10$} \\
\hline $6 \alpha$ & $1.35(1 \mathrm{H}, \mathrm{m})$ & \multirow{2}{*}{$20.4(\mathrm{t})$} & \multirow{2}{*}{$\mathrm{CH}_{2}$} & \multirow{2}{*}{$\mathrm{H}-7$} & \\
\hline $6 \beta$ & $1.01(1 \mathrm{H}, \mathrm{m})$ & & & & \\
\hline $7 \alpha$ & $1.39(1 \mathrm{H}, \mathrm{m})$ & \multirow{2}{*}{$32.4(\mathrm{t})$} & \multirow{2}{*}{$\mathrm{CH}_{2}$} & \multirow{2}{*}{ H-6 } & \\
\hline $7 \beta$ & $1.11(1 \mathrm{H}, \mathrm{m})$ & & & & \\
\hline 8 & \multirow{3}{*}{$1.63(1 \mathrm{H}, \mathrm{t}, J=7.7,8.7)$} & $40.0(\mathrm{~s})$ & $\mathrm{C}$ & & \\
\hline 9 & & $47.9(\mathrm{~d})$ & $\mathrm{CH}$ & & \\
\hline 10 & & $36.1(\mathrm{~s})$ & $\mathrm{C}$ & & \\
\hline $11 \alpha$ & $1.86(1 \mathrm{H}, \mathrm{m})$ & \multirow{2}{*}{$23.6(\mathrm{t})$} & \multirow{2}{*}{$\mathrm{CH}_{2}$} & \multirow{2}{*}{$\mathrm{H}-12$} & \multirow{5}{*}{ C-9, C-14 } \\
\hline $11 \beta$ & $1.86(1 \mathrm{H}, \mathrm{m})$ & & & & \\
\hline 12 & $5.44(1 \mathrm{H}$, br s $)$ & $122.7(\mathrm{~d})$ & $\mathrm{CH}$ & $\mathrm{H}-11$ & \\
\hline 13 & & $144.2(\mathrm{~s})$ & $\mathrm{C}$ & & \\
\hline 14 & & $42.1(\mathrm{~s})$ & $\mathrm{C}$ & & \\
\hline $15 \alpha$ & $1.13(1 \mathrm{H}, \mathrm{m})$ & \multirow{2}{*}{$28.2(\mathrm{t})$} & \multirow{2}{*}{$\mathrm{CH}_{2}$} & \multirow{2}{*}{$\mathrm{H}-16$} & \\
\hline $15 \beta$ & $2.10(1 \mathrm{H}, \mathrm{m})$ & & & & \\
\hline $16 \alpha$ & $2.16(1 \mathrm{H}, \mathrm{m})$ & \multirow{2}{*}{$23.7(t)$} & & & \\
\hline $16 \beta$ & $2.03(1 \mathrm{H}, \mathrm{m})$ & & $\mathrm{CH}_{2}$ & H-15 & C-18 \\
\hline 17 & & $47.0(\mathrm{~s})$ & $\mathrm{C}$ & & \\
\hline 18 & $3.18(1 \mathrm{H}, \mathrm{dd}, J=4.4)$ & $47.8(\mathrm{~d})$ & $\mathrm{CH}$ & H-19 & $\begin{array}{l}\text { C-12, } \\
\text { C-13 }\end{array}$ \\
\hline $19 \alpha$ & $2.62(1 \mathrm{H}, \mathrm{t}, J=13.7,13.3)$ & & & & C-18, \\
\hline $19 \beta$ & $2.22(1 \mathrm{H}, \mathrm{m})$ & $41.9(\mathrm{t})$ & $\mathrm{CH}_{2}$ & $\mathrm{H}-18$ & C-20, \\
\hline 20 & & $149.0(\mathrm{~s})$ & $\mathrm{C}$ & & C-29 \\
\hline $21 \alpha$ & $1.16(1 \mathrm{H}, \mathrm{m})$ & $304(t)$ & $\mathrm{CH}_{2}$ & H_2? & $C-20$ \\
\hline $21 \beta$ & $2.28(1 \mathrm{H}, \mathrm{m})$ & $30.4(t)$ & $\mathrm{CH}_{2}$ & $\mathrm{H}-22$ & $C-20$ \\
\hline $22 \alpha$ & $1.87(1 \mathrm{H}, \mathrm{m})$ & $383(t)$ & & H_21 & $C-20$ \\
\hline $22 \beta$ & $2.18(1 \mathrm{H}, \mathrm{m})$ & $38.3(\mathrm{t})$ & $\mathrm{CH}_{2}$ & $\mathrm{H}-21$ & $C-20$ \\
\hline 23 & $9.73(1 \mathrm{H}, \mathrm{s})$ & $206.8(\mathrm{~s})$ & $\mathrm{CHO}$ & & C-4, C-24 \\
\hline 24 & $1.27(3 \mathrm{H}, \mathrm{s})$ & $10.4(q)$ & $\mathrm{CH}_{3}$ & & $\begin{array}{l}\text { C-3, C-4, } \\
\text { C-5, C-23 }\end{array}$ \\
\hline 25 & $0.77(3 \mathrm{H}, \mathrm{s})$ & $15.5(q)$ & $\mathrm{CH}_{3}$ & & C-9 \\
\hline 26 & $0.89(3 \mathrm{H}, \mathrm{s})$ & $17.2(\mathrm{q})$ & $\mathrm{CH}_{3}$ & & C-7, C-9 \\
\hline 27 & $1.24(3 \mathrm{H}, \mathrm{s})$ & $26.1(q)$ & $\mathrm{CH}_{3}$ & & $\begin{array}{c}\text { C-9, C-13, } \\
\text { C-15 }\end{array}$ \\
\hline 28 & & $179.3(\mathrm{~s})$ & C & & \\
\hline $29 \alpha$ & $4.78(1 \mathrm{H}, \mathrm{s})$ & $1070(t)$ & $\mathrm{CH}_{\mathrm{H}}$ & & C-19, \\
\hline $29 \beta$ & $4.73(1 \mathrm{H}, \mathrm{s})$ & $107.0(\mathrm{t})$ & $\mathrm{CH}_{2}$ & & C-21 \\
\hline $1^{\prime}$ & $4.84(1 \mathrm{H}, \mathrm{d}, J=7.8)$ & $105.0(\mathrm{~d})$ & $\mathrm{CH}$ & H-2' & $C-3$ \\
\hline $2^{\prime}$ & $3.88(1 \mathrm{H}, \mathrm{m})$ & $75.0(\mathrm{~d})$ & $\mathrm{CH}$ & $\mathrm{H}-1^{\prime}$ & $C-1^{\prime}$ \\
\hline $3^{\prime}$ & $4.17(1 \mathrm{H}, \mathrm{m})$ & $78.0(\mathrm{~d})$ & $\mathrm{CH}$ & $\mathrm{H}-4^{\prime}$, & $C-4^{\prime}, C-5^{\prime}$ \\
\hline $4^{\prime}$ & $4.21(1 \mathrm{H}, \mathrm{m})$ & $73.3(\mathrm{~d})$ & $\mathrm{CH}$ & $\mathrm{H}-3^{\prime}, \mathrm{H}-5^{\prime}$ & C- $3^{\prime}$ \\
\hline $5^{\prime}$ & $4.27(1 \mathrm{H}, \mathrm{m})$ & $77.8(\mathrm{~d})$ & $\mathrm{CH}$ & $\mathrm{H}-4^{\prime}$ & $C-4^{\prime}$ \\
\hline $6^{\prime}$ & & $179.3(\mathrm{~s})$ & $\mathrm{C}$ & & \\
\hline
\end{tabular}

The 6 nortriterpenoid saponins and 5 triterpenoid saponins were evaluated for their inhibitory activities on plant pathogenic fungus. As showed in Table 2, compounds 3, 4, 5, 6, 7, 10 and 11 demonstrated potent inhibitory activities against Colletotrichum gloeosporioides, while compounds $\mathbf{1}$, 2, 8 and 9 were inactive. The compound $\mathbf{1 1}$ was the most active of these compounds, with $69.21 \%$ inhibition at $100 \mu \mathrm{g} / \mathrm{mL}$ after $72 \mathrm{~h}$. To determine the broad-spectrum inhibitory activity of compound $\mathbf{1 1}$ against plant pathogenic fungi, it was tested against Alternaria alternata, A. solani, Botrytis cinerea, 
C. alterosporioides, Fusarium graminearum, F. verticilloides, Thanatephorus cucumeris, Sclerotinia sclerotiorum. As shown in Table 3, compound $\mathbf{1 1}$ exhibited inhibitory activity against all of the tested pathogenic fungi and showed the highest activity against $B$. cinerea and T. cucumeris, with $\mathrm{EC}_{50}$ values of $13.6 \mu \mathrm{g} / \mathrm{mL}$ and $13.9 \mu \mathrm{g} / \mathrm{mL}$ respectively. The $\mathrm{EC}_{50}$ values of compound $\mathbf{1 1}$ against the other six pathogenic fungi were between 19.4 and $36.3 \mu \mathrm{g} / \mathrm{mL}$. To the best of our knowledge, this study represented the first report on significant antifungal potential of saponins of S. bigelovii.

Table 2. Inhibitory activities of compounds 1-11 (100 mg/mL) against C. gloeosporioides.

\begin{tabular}{lcccccccccccc}
\hline \multirow{2}{*}{ Pathogenic Fungi } & \multicolumn{10}{c}{ Inhibition after $\mathbf{7 2} \mathbf{h}(\mathbf{\%})$} \\
\cline { 2 - 12 } & $\mathbf{1}$ & $\mathbf{2}$ & $\mathbf{3}$ & $\mathbf{4}$ & $\mathbf{5}$ & $\mathbf{6}$ & $\mathbf{7}$ & $\mathbf{8}$ & $\mathbf{9}$ & $\mathbf{1 0}$ & $\mathbf{1 1}$ & AMB \\
\hline C. gloeosporioides & -2.53 & -5.24 & 27.61 & 24.15 & 13.65 & 14.77 & 33.27 & -1.90 & -1.48 & 7.54 & 69.21 & 73.89 \\
\hline
\end{tabular}

Table 3. Inhibitory activities of compound $\mathbf{1 1}$ against seven pathogenic fungi $\left(\mathrm{EC}_{50}, \mu \mathrm{g} / \mathrm{mL}\right)$.

\begin{tabular}{cc}
\hline Pathogenic Fungi & $\mathbf{1 1}$ \\
\hline A. alternata & $31.8 \pm 1.3$ \\
A. solani & $23.3 \pm 1.5$ \\
B. cinerea & $13.6 \pm 0.6$ \\
C. gloeosporioides & $34.0 \pm 0.9$ \\
F. graminearum & $28.8 \pm 1.7$ \\
F. verticilloides & $19.4 \pm 1.1$ \\
T. cucumeris & $13.9 \pm 0.7$ \\
S. sclerotiorum & $36.3 \pm 2.1$ \\
\hline
\end{tabular}

\section{Materials and Methods}

\subsection{General Experimental Procedures}

Melting points were measured using a XT-4 Boetius micro melting point apparatus (Beijing, China). Specific rotations were obtained on a Perkin-Elmer 341 digital polarimeter (Waltham, MA, USA). IR spectra were taken as the $\mathrm{KBr}$ discs on a Thermo Nicolet Nexus 870 FT-IR E.S.P. spectrometer (Beijing, China). High resolution electrospray ionization mass spectroscopy (HR-ESI-MS) spectra were recorded on an Agilent 1260 UPLC DAD 6530 Q-TOF mass spectrometer (Santa Clara, CA, USA). Nuclear magnetic resonance (NMR) data were acquired in pyridine- $d_{5}$ on a Bruker DRX500 NMR spectrometer (Beijing, China) with ${ }^{1} \mathrm{H}$ - and ${ }^{13} \mathrm{C}-\mathrm{NMR}$ observed at 500 and $125 \mathrm{MHz}$. Silica

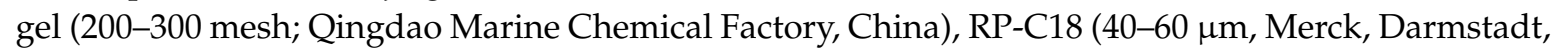
Germany) and Sephadex LH-20 (GE Healthcare Life Sciences, Shanghai, China) were used for column chromatography (CC). Thin-layer Chromatography (TLC) analysis was performed using on Silica gel GF254 plates (10-40 $\mu \mathrm{m}$; Qingdao Marine Chemical Factory, Qingdao, China).

\subsection{Plant Material}

Herbs of S. bigelovii Torr. were collected from the beach of Yancheng, Jiangsu Province, China, in June 2013 and identified by Changqi Yuan, a professor at Institute of Botany, Jiangsu Province and Chinese Academy of Sciences, China. A voucher specimen (No. 13-03) was deposited with the Herbarium, Institute of Botany, Jiangsu Province and Chinese Academy of Sciences.

\subsection{Extraction and Isolation}

The air-dried powder of the herbs $(5 \mathrm{~kg})$ of $\mathrm{S}$. bigelovii was extracted by $80 \%$ ethanol $(3 \times 150 \mathrm{~L})$ at room temperature $\left(25^{\circ} \mathrm{C}\right)$ for $72 \mathrm{~h}$ each time. The solvent was evaporated under reduced pressure, leaving an extract $(651 \mathrm{~g})$ that was suspended in hot $\mathrm{H}_{2} \mathrm{O}\left(60{ }^{\circ} \mathrm{C}, 2000 \mathrm{~mL}\right)$. The suspension was partitioned successively with equal volumes of petroleum ether (PE), ethyl acetate (EtOAc) and 
$n$ - $\mathrm{BuOH}$. The $n$ - $\mathrm{BuOH}$-soluble fraction was concentrated under a vacuum to produce the $n$ - $\mathrm{BuOH}$ extraction product $(260.2 \mathrm{~g}, 0.52 \%)$. The $n-\mathrm{BuOH}$-soluble fraction was subjected to silica-gel CC (1200 g, 200-300 mesh), eluted with a gradient of $\mathrm{CH}_{2} \mathrm{Cl}_{2}-\mathrm{MeOH}-\mathrm{H}_{2} \mathrm{O}$ (95:5:0 to 0:100:0, v/v/v) to obtain eight fractions (Fr.1-Fr.8). Fr.2 (21.16 g) was separated through a Sephadex LH-20 CC [250 g, $\left.\mathrm{CH}_{2} \mathrm{Cl}_{2}: \mathrm{MeOH}(1: 1), v / v\right]$ to give five subfractions (Fr.2-1-Fr.2-5), and Fr.2-3 (1.5 g) was further subjected to RP-C18 CC ( $250 \mathrm{~g}, 50 \mu \mathrm{m})$ with MeOH:H $\mathrm{H}_{2} \mathrm{O}(90: 10-0: 100 \mathrm{v} / v)$ and RP-HPLC [MeOH: $\mathrm{H}_{2} \mathrm{O}$ $(34: 66, v / v)$ ] to provide compound $1(13.67 \mathrm{mg})$ and $2(11.49 \mathrm{mg})$. Fr.3 (17.29 g) was separated by silica-gel CC (150 g, 200-300 mesh) with a gradient elution of EtOAc-MeOH (100:0 to 0:100, $v / v)$ to obtain seven subfractions (Fr.3-1-Fr.3-8). Fr.3-1 and Fr.3-2 was purified using a Sephadex LH-20 CC with a $\mathrm{CHCl}_{3}: \mathrm{MeOH}$ eluent $(1: 1, v / v)$ to give compound $3(12.43 \mathrm{mg})$ and compound $4(17.39 \mathrm{mg})$, respectively. Fr.4 (37.53 g) was separated by RP-C18 $(150 \mathrm{~g}, 50 \mu \mathrm{m})$ and eluted with $\mathrm{MeOH}-\mathrm{H}_{2} \mathrm{O}$ $(80: 20 \rightarrow 0: 100, v / v)$ to produce nine subfractions (Fr.4-1-Fr.4-9). Fr.4-3 (153.93 mg) was purified by RP-HPLC [MeOH: $\left.\mathrm{H}_{2} \mathrm{O}(70: 30, v / v)\right]$ to give compound $5(17.34 \mathrm{mg})$ and 6 (14.43 mg). Fr.4-4 (1037.61 mg) was purified by RP-HPLC [MeOH: $\left.\mathrm{H}_{2} \mathrm{O}(45: 55, v / v)\right]$ to give compound 7 (619.37 mg). Fr.4-5 (1025.47 mg) was purified by RP-HPLC using [MeOH: $\left.\mathrm{H}_{2} \mathrm{O}(65: 35, v / v)\right]$ to give compound $8(521.92 \mathrm{mg})$ and $9(16.33 \mathrm{mg})$. Fr.5 (17.61 g) was separated through Sephadex LH-20 CC [250 g, $\mathrm{CH}_{2} \mathrm{Cl}_{2}: \mathrm{MeOH}(1: 1), v / v$ ] to give three subfractions (Fr.5-1 $\rightarrow$ Fr.5-3). Fr.5-2 (1.7 g) was further separated via RP-C18 CC $(250 \mathrm{~g}, 50 \mu \mathrm{m})$ with $\mathrm{MeOH}-\mathrm{H}_{2} \mathrm{O}(100: 0 \rightarrow 30: 70, v / v)$ and purified by RP-HPLC [MeOH: $\left.\mathrm{H}_{2} \mathrm{O}(74: 26, v / v)\right]$ to provide compound $10(16.57 \mathrm{mg})$ and $\mathbf{1 1}(14.47 \mathrm{mg})$.

Compound 11: white amorphous powder, m.p. $205-206{ }^{\circ} \mathrm{C},[\alpha]_{\mathrm{D}}^{20}+27.9($ c $0.479, \mathrm{MeOH}), \mathrm{IR}$ $v_{\max } \mathrm{cm}^{-1}: 3412,1705$ and 1645, HREI-MS (negative ion mode) $\mathrm{m} / \mathrm{z}: 629.3261[\mathrm{M}-\mathrm{H}]^{-}$(calc. for $\left.\mathrm{C}_{35} \mathrm{H}_{49} \mathrm{O}_{10}, 629.3285\right) .{ }^{1} \mathrm{H}-\mathrm{NMR},{ }^{13} \mathrm{C}-\mathrm{NMR}, \mathrm{DEPT},{ }^{1} \mathrm{H}-{ }^{1} \mathrm{H}$ COSY and HMBC data see Table 1.

\subsection{Fungus Strains and Positive Controls}

The pathogens, Alternaria alternata, A. solani, Botrytis cinerea, Colletotrichum gloeosporioides, Fusarium graminearum, F. verticilloides, Thanatephorus cucumeris, Sclerotinia sclerotiorum, used in the bioassays were identified by Pingping Song, at Institute of Botany, Jiangsu Province and Chinese Academy of Sciences, China. Positive controls Amphotericin B (AMB) was purchased from Sigma-Aldrich (St Louis, MO, USA).

\subsection{Antifungal Assays in Vitro}

Inhibitory activity against the hyphal growth of pathogenic fungus was determined using a growth rate method [12]. A test solution with the required concentration can be made by dissolving the sample in DMSO. $1 \mathrm{~mL}$ of this solution and $24 \mathrm{~mL}$ of PDA molten agar medium were mixed thoroughly and distributed equally into 3 petri dishes $(6 \mathrm{~cm}$ diameter). DMSO, without any sample, was processed similarly to produce the control culture media. Then a toxic culture media can be made. The discs of hyphae, which was cut from the edge of the colony and had been incubated in advance, was put downward in the middle of culture medium's surface. By the least-squares method, we can acquire the discs, regression equations, $\mathrm{EC}_{50}$ and $95 \%$ confidence intervals.

\section{Conclusions}

In the present study, a new nortriterpenoid saponin (11) was isolated from the herbs of S. bigelovii, and it has a significant inhibitory effect on plant pathogenic fungus. Comparison of the structures of compound 3, 4, 5, 6, 7, 10 and 11 with those of inactive compounds, suggested that the aldehyde group at C-23, the carboxyl group at C-28 and the ester group at C-6' of glucuronopyranosyl moiety might have contributed to the inhibition of the growth of $C$. gloeosporioides synergistically.

Supplementary Materials: Supplementary materials can be accessed at: http://www.mdpi.com/1420-3049/ 20/11/19695/s1. 
Acknowledgments: This work was financially supported by the Foundation of Jiangsu Key Laboratory for Bioresources of Saline Soils (JKLBS2012009) and the Science and Technology Foundation of Jiangsu Province (BM2015019).

Author Contributions: Xu Feng and Qizhi Wang organized the study. Yu Shan, Yu Chen, Min Yin and Ming Wang performed the experiments. Yu Shan, Huan Li and Fuqin Guan analyzed the results. Yu Shan wrote the manuscript.

Conflicts of Interest: The authors declare no conflicts of interest.

\section{References}

1. Wang, Q.Z.; Liu, X.F.; Shan, Y.; Guan, F.Q.; Chen, Y.; Wang, X.Y.; Wang, M.; Feng, X. Two new nortriterpenoid saponins from Salicornia bigelovii Torr. and their cytotoxic activity. Fitoterapia 2012, 83, 742-749. [CrossRef] [PubMed]

2. Glenn, E.P.; O'Leary, J.W.; Watson, M.C.; Thompson, T.L.; Kuehl, R.O. Salicornia bigelovii Torr.: An oilseed halophyte for seawater irrigation. Science 1991, 251, 1065-1067. [CrossRef] [PubMed]

3. Guan, F.Q.; Shan, Y.; Zhao, Y.Y.; Wang, Q.Z.; Wang, M.; Sun, H.; Feng, X. Research development on pharmacological activities and mechanism of Salicornia plants. Chin. Pharm. Bull. 2013, 29, 1188-1191.

4. Kim, J.Y.; Cho, J.Y.; Ma, Y.K.; Park, K.Y.; Lee, S.H.; Ham, K.S.; Lee, H.J.; Park, K.H.; Moon, J.H. Dicaffeoylquinic acid derivatives and flavonoid glucosides from glasswort (Salicornia herbacea $\mathrm{L}$.) and their antioxidative activity. Food Chem. 2011, 125, 55-62. [CrossRef]

5. Zhao, Y.; Wang, X.; Wang, H.; Liu, T.; Xin, Z. Two new noroleanane-type triterpene saponins from the methanol extract of Salicornia herbacea. Food Chem. 2014, 151, 101-109. [CrossRef] [PubMed]

6. Kim, Y.A.; Kong, C.S.; Lee, J.I.; Kim, H.; Park, H.Y.; Lee, H.S.; Lee, C.; Seo, Y. Evaluation of novel antioxidant triterpenoid saponins from the halophyte Salicornia herbacea. Bioorg. Med. Chem. Lett. 2012, 22, 4318-4322. [CrossRef] [PubMed]

7. Li, J.; Jadhav, A.N.; Khan, I.A. Triterpenoids from brazilian ginseng, Pfaffia paniculata. Planta Med. 2010, 76, 635-639. [CrossRef] [PubMed]

8. Chen, Y.; Feng, X.; Wang, M.; Jia, X.; Zhao, Y.; Dong, Y. Triterpene glycosides from Lonicera. II isolation and structural determination of glycosides from flower buds of Lonicera macranthoides. Chem. Nat. Compd. 2009, 45, 514-518.

9. Fang, J.B.; Yao, Z.; Chen, J.C.; Liu, Y.W.; Takaishi, Y.; Duan, H.Q. Cytotoxic triterpene saponins from Alternanthera philoxeroides. J. Asian Nat. Prod. Res. 2009, 11, 261-266. [CrossRef] [PubMed]

10. Yang, L.; Jiang, H.; Wang, Q.H.; Yang, B.Y.; Kuang, H.X. A new feruloyl tyramine glycoside from the roots of Achyranthes bidentata. Chin. J. Nat. Med. 2012, 10, 16-19. [CrossRef] [PubMed]

11. Espada, A.; Rodriguez, J.; Villaverde, M.C.; Riguera, R. Hypoglucaemic triterpenoid saponins from Boussingaultia baselloides. Can. J. Chem. 1990, 68, 2039-2044. [CrossRef]

12. Song, Q.Y.; Qi, W.Y.; Li, Z.M.; Zhao, J.; Chen, J.J.; Gao, K. Antifungal activities of triterpenoids from the roots of Astilbe myriantha Diels. Food Chem. 2011, 128, 495-499. [CrossRef] [PubMed]

Sample Availability: Samples of the compounds 1-11 are not available from the authors.

(C) 2015 by the authors; licensee MDPI, Basel, Switzerland. This article is an open access article distributed under the terms and conditions of the Creative Commons by Attribution (CC-BY) license (http:/ / creativecommons.org/licenses/by/4.0/). 